\title{
Of Sound Mind: Mental Distress and Sound in Twentieth-Century Media Culture
}

'Psychotic delusions constitute a shadow history of electrical communication in the 2oth century'. ${ }^{\text {. }}$

\section{Seeing the insane}

The visual arts have long been a repository for representations of those experiencing mental distress. Sander L. Gilman's I982 cultural history Seeing the Insane offered one of the first major analyses of visual motifs for representing madness, spanning from the Middle Ages to the late nineteenth century. ${ }^{2}$ In particular, Gilman focused on two categories of artistic production: works that try to approximate the subjective experience of madness ('the world of the insane') as well as those that address madness in the social realm ('the insane in the world'). ${ }^{3}$ This ground-breaking study traced such depictions across a variety of visual media, from sketches and etchings to painting and photography, which were analysed in view of changes in the treatment and discourse of madness in Western art and medicine. Gilman's approach prefigured later developments in the interdisciplinary field of visual culture studies, in which scholars have often performed analyses that examine particular visual motifs from cross-medial and transhistorical perspectives. ${ }^{4}$

One shortcoming of Gilman's study is that it stops short of examining visual representations of madness and the body after I900. His periodization until the late nineteenth century means that subsequent motifs in photography, cinema and television, and their relation to the understanding and treatment of mental disturbance remain unexplored. ${ }^{5}$ In the epilogue to his study, Gilman affirms that stereotypical visualisations of madness certainly continued into the twentieth century and up to the present. However, he provides a rationale for this periodization based on the exclusion of the visual from Freudian psychoanalysis around I900. In the late nineteenth century, as Gilman asserts, there was a shift in emphasis toward sound, with psychoanalysis developing an analytic technique based on listening. ${ }^{6}$ The ramifications of this shift in emphasis - on sound and listening - is given short shrift compared with Gilman's previous detailed account of visual techniques and motifs for representing mental illness and the body.

Gilman's study represents an important touchstone, which reveals historical understandings of mental illnesses in terms of experienced symptoms (visions, hallucinations) as well as visual techniques in representation. In its wake, there have been numerous publications elaborating on the visual motifs of madness in art, film and television, and, in some cases, the impact of stereotypical representations on public discourses and attitudes about mental illness.7 Parallel to 
these visual studies and discourse analyses of madness in media, a growing number of scholars have pointed to historical coincidence between media, modernity and psychiatric diagnoses of illnesses like schizophrenia. ${ }^{8}$ Such scholarship draws attention to the significance of the rise of modern sound technologies from the nineteenth century onwards, such as sound telegraphy, telephony and phonography and wireless radio. This historical development from the nineteenth century onwards has provided an elaboration and extension of Gilman's account, with studies focusing on the ways that sound media technologies were posited as models for or causes of mental distress, but also as the potential cure or means for of organising this experience. ${ }^{9}$

The current article seeks to specify the representation of mental disturbance in sound media during the twentieth century. In one sense, it follows Gilman's lead in examining representations of 'the world of the insane' and 'the insane in the world'. These two categories allow for a consideration of how mental distress has been approximated and narrated through mediated sound, but also thematized as a social issue within sound media. This article also takes up Gilman's task to observe such motifs across multiple social contexts and historical eras. This perspective is consistent with recent scholarship in sound studies, which - in a similar vein to visual culture studies - has called for attention to transhistorical perspectives on modern sound culture. ${ }^{\text {Io }}$ Unlike most existing scholarship, however, the current analysis will engage perspectives on societal and technological change across the twentieth century as crucial for aesthetic strategies developed in radio and sound film production. In other words, we seek to examine the connections between sound culture and (constructions of) madness as these have recurred in various social, cultural and technical configurations.

In what follows, recent research about modern media and mental illness will be taken as a departure point, in order to establish the ways in which certain symptoms have been understood in relation to broadcast media in particular, and the related circulation of metaphors or pathologies of media. The notion of radio's status as a technology based on the disembodied or 'acousmatic' voice is central to this article; we reflect on the nature of mediated sound and how its relationships to the body both shatter and reconstruct subjectivity - appearing by turns as both cause and (talking) cure. ${ }^{\text {II }}$ Therefore, alongside scholarship about the narrative techniques enabled by acousmatic sound, we will reflect on the historical-discursive formation of modern media technologies in terms of the psyche and mental distress. The definition of 'mental distress' is thus somewhat broader than clinical definitions, and is taken to encompass a scope of afflictions from schizophrenia and hysteria to neurosis and trauma. ${ }^{12}$ The analysis engages with sonic representations of mental distress through a number of media moments, from Orson Welles' famous THE WAR OF THE WORLDS broadcast and avant-garde radio to the expanded sound design techniques from the I970s onwards in cinema. Not only technological developments - in tape technology, cinema surround sound and digital editing - are crucial in each case, but also an acknowledgement of the changing social functions of the media themselves and the context in which consumption takes place.

\section{Too Many Voices: Mental Distress and Media History}

Since the nineteenth century, modern media have often been understood in metaphorical terms, as an embodiment of modernity and its related changes in the experience of time and space. In 
media historical research, as Christopher Anderson and Michael Curtin point out, it is important to attend the ways that metaphors and metonyms variously frame our understanding of media according to the technological apparatus and its operation, or in their institution structures or social formations. Scholarship in recent decades, as they note, has generated the recognition that media are

'[...] not given facts that precede historical investigation or the bedrock upon which any historical investigation takes place; they are ongoing social productions, defined and redefined through use, affected not only by events and material conditions, but, crucially, by the language used to describe and discuss them'. ${ }^{.3}$

In other words, the practice of media history has been increasingly influenced by insights derived from both cultural and social history, with particular attention to the contexts in which audiences engage with media. In the following, we will take a particular focus on the social discourses and metaphors linking madness to sound technologies, whether posited as symptom or cure for mental disturbances.

Broadcast media in particular, have often been a site for metaphors about mental illness, with wireless radio considered an 'etheric bedlam' or 'giant nuthouse' filled with multiple, overlapping and uncanny voices. ${ }^{\mathrm{I4}}$ The notion of amateur radio operators as being 'radio mad' was part of the popular discourse of I920s radio. ${ }^{15}$ This affliction - coined as Radiotismus - was initially attributed to male radio hobbyists who listened via crystal detector sets. ${ }^{16}$ The labour involved in operating and listening to early radio was often posed in terms of being possessed by faraway voices and music, with its placement in the attic competing with family time in the domestic hearth. ${ }^{17}$ With the institutionalisation of broadcasting, promoting radio as a medium for uniting the family in the domestic living room, this typology of radio illness shifted. Indeed, in the historical stereotypes of mental and nervous illness, it is often women who were framed in terms of technologically-induced madness or overstimulation.$^{18}$ In the case of radio, the diagnosis of Radiotismus was increasingly applied to women, who were deemed as affecting by listening too much to radio. Once headsets were no longer necessary, with new models with loudspeaker amplification, the diagnosis extended to women who experienced nervousness or overwhelming due to excessive listening while performing other (presumably household) tasks. ${ }^{19}$ In other words, 'radio madness' was initially linked to a general fascination with the technological device, in line with its early civilian uses by former World War I soldiers and male tinkers (Bastler). ${ }^{20}$

Following the domestication of radio, the medium was portrayed as potentially causing disturbances in female listeners, with the implication that their nerves could not handle the sensory input of radio's mediated voices. In what follows, however, women's voices are largely rendered absent from radio discourse and a concern with madness against the background of the institutionalisation of radio and the establishment of its modes of address, generic conventions and programme schedule from the I920s onwards. One might say, however, the forms of informal address in daytime radio, was intended to sooth (or provide a listening 'cure' for) its imagined female domestic audience. In broadcast radio, the male radio voice was normalised as a sign of authority, particularly in state-administered systems like Britain and Germany. In the 
context of economic depression in the I930s, moreover, radio was conceived as a 'social glue', one that would reassure listeners amidst crises of cultural identity, the economy and international relations. ${ }^{21}$ Earlier notions of radio in terms of disembodiment and fantasy were downplayed in favour of affirming its ability to ease these tensions, with light entertainment programming such as music, variety and sport. ${ }^{22}$

One of the key aspects in modern sound technologies that have been thematized in terms of the uncanny or insanity is that they separate the voice from the body, and the site of speaking from its listening context. In the nineteenth century, the telephone was described as splitting the voice of the speaking subject into either end of the telephone line. ${ }^{23}$ The gramophone not only enabling the 'canning' of voices, but also the possibility of recording vocal sounds of nonsense or 'speaking in tongues'. ${ }^{24}$ The radio, too, has been put in similar terms, for instance in the writings of Canadian composer R. Murray Schafer. Writing in the late I96os, he expressed his dissatisfaction with the proliferation of sound media in public life, as summed up by his term schizophonia. This metaphorical use of schizophrenia was to draw attention to the 'split effect' that occurs between the original context of the sound and its reproduction in multiple forms. The pathological associations of the word schizophonia as a quality of the technology, which causes sounds to lose their contextual meaning, but also figures as a metaphor for mental disturbance or confusion in the individual listener and society as a whole.

In a less polemic account, film scholar Michel Chion has developed the notion of acousmatic sound - defined as those heard without their source being seen or shown - as an analytical category. ${ }^{25}$ Radio and the telephone, in particular, are defined as acousmatic media technologies. Chion points to the medial qualities of radio as a sound-based medium, and its potential to appeal to the imagination through its deployment of disembodied voices:

'People speaking on the radio are acousmêtres in that there's no possibility of seeing them; this is the essential difference between them and the filmic acousmêtre. In radio one cannot play with showing, partially showing, and not showing. (...) Cinema has a frame, whose edges are visible; we can see where the frame leaves off and offscreen space starts. In radio, we cannot perceive where things 'cut,' as sound itself has no frame'. ${ }^{26}$

In film sound, as Chion's work has shown, a voice separated from its body, emanating from offscreen space, creates as an acousmatic voice. This disembodied voice seems to come from everywhere, as can be observed in Fritz Lang's tHe TESTAMENT OF DR. MABUSE (I933). The key difference from radio, he argues, is that the sound film can experiment with relationship of the voice to body and subjecthood. The acousmêtre, a figure that is heard but not seen, may be temporarily off-screen or rarely (or never) visualised for the audience. It is precisely the relationship of the acousmêtre's voice to the image track, defined as 'neither inside nor outside', which lends itself to associations with the uncanny, mental disturbance, intrigue or omnipotence.

We will draw on Chion's account for its useful terminology when considering mediated sound and voice-body relationships. Nonetheless, the strong psychoanalytic undercurrent to Chion's thinking often compromises reflections on the historical specificity of sound in media. In order to gain a broader sense of the historical relationship between mental illness and mod- 
ern media, John Durham Peters provides an instructive account in his 2010 essay 'Broadcasting and Schizophrenia'. ${ }^{27}$ Peters establishes the historical coincidences between psychiatry and modern communications technology from the late nineteenth century onwards. For key thinkers from around I900, such as Sigmund Freud or Karl Jaspers, the psyche and its treatment was crucial to understanding modernity and modern communication. ${ }^{28}$ Peters notes that the cultural and biological influences on mental illness have been debated extensively. While some scholars see (broadcast) media as offering vivid metaphors for the delusional, others have pointed to the constitutive or at least influential role of modern media on the symptoms diagnosed as schizophrenia, and their historical coincidence in the late nineteenth century. ${ }^{29}$ Peters then traces the historical process in broadcasting whereby personal address came to be understood as impersonal. As he points out, radio pioneers learned to generate 'sociability through the ears and conversation without interaction - something historically reserved for madness or religious experience' $3^{\circ}$ The recognition of broadcasting's impersonal address was posited in opposition to the personal interaction facilitated through the telephone. From the igIos, normative conceptions of broadcasting in the United States confirmed an ideal of regulated airwaves:

'A plural public and a unitary self were for much of the 2oth century the two official options for rational agents, the norms of sane communication. Deviations were pathologies: a single voice in media was totalitarian; many voices in mind meant madness. A monopolized public was the danger of fascism; a pluralized self was the danger of schizophrenia'. ${ }^{\text {I }}$

There are two lingering pathologies where subjects do not understand these norms of communication, which Peters treats as the historical persistence of telepathy within psychiatric diagnoses: 'thought broadcasting' and 'delusions of reference'. With thought broadcasting, the subject feels as if they are a transmitter, with their private thoughts broadcast to the public, whereas with delusions of reference there is confusion in reception, with the subject perceiving public broadcast as addressing them personally. In other words, there is a deeply historical relationship between sound technologies - like telegraphy, telephony and wireless radio - and the pathologies and metaphors of madness developed from the nineteenth century onwards. In what follows, we will specify the ways in which sound-specific strategies for approximating and representing mental illness have figured in twentieth-century media culture.

\section{Staging Mental Distress with Acousmatic Sound}

\section{USA}

It has been shown above how the historical associations of wireless transmission with chaos and madness, particularly during disasters like the I9I2 Titanic sinking, were downplayed by national broadcast regulation of the airwaves in the I9Ios and I920s. It might be said that the established programming of broadcast radio sought to sooth national radio audiences, with radio acting as a 'social glue' in the wake of the economic depression and international diplomatic crises during the I930s. ${ }^{32}$ Here, however, we will investigate key media texts for considering the techniques developed for using mediated sound - particularly in the form of the disembodied 
voice - to approximate and sometimes instigate mental distress in radio and sound film.

The potential of radio for producing anxiety or hysteria amongst listeners in Depression-era radio is often linked to the live CBS broadcast of THE WAR OF THE WORLDS in October I938, which was claimed to cause 'mass panic' amongst its estimated six million listeners. 33 Media reporting about Orson Welles' adaptation of H.G. Wells' I898 science fiction novel - for The Mercury Theater on the Air - included physiological problems and suicide to traffic incidents, people fleeing on foot and gathering in churches to pray together. Before considering the specific sound techniques used in this dramatized studio performance, it is worth dwelling on the genre of the emergency news report, as listeners in this period were privy to the increasingly rapid processes of global newsgathering. A good example of a listener's bewilderment about this steady stream of breaking news stories, updates and location reporting is indicated in the following quote from an American listener in the late i930s:

'Being in a troublesome world, anything is liable to happen. We hear so much news every day. So many things we hear are unbelievable. Like all of a sudden six hundred children burned to death in a school fire. Or a lot of people thrown out of work. Everything seems to be a shock to me'. ${ }^{34}$

The mass experience of disaster reportage was also one of the new experiences ushered in with broadcasting, and it reveals the potential of acousmatic sound to appeal and unsettle listeners. ${ }^{35}$ One of the most striking reportages of a disaster was that of wLS Chicago commentator Herbert Morrison, who gave an emotional account of the Hindenburg airship crash in May I937:

'It's practically standing still now; they've dropped ropes out of the nose of the ship, and it's been taken a hold-of down on the field by a number of men. The back motors of the ship are just holding it, just enough to keep it - It burst into flames! Get out of the way! Get out of the way! (...) This is one of the worst catastrophes in the world' ${ }^{36}$

One year after Morrison's distressed reportage, Welles' THE WAR OF THE WORLDS gave a similar sense of live action unfolding, as music recital is ostensibly interrupted by repeated 'news flash' updates. ${ }^{37}$ The impression given by spontaneous interruptions and switches between pregnant pauses and frantic activity - overlaying multiple voices and sounds - are crucial components for the loss of orientation and the build-up of suspense generated during the forty-odd minutes of studio performance. In order to illustrate the sound techniques employed, two key scenes will now be taken as a case in point for the use of radio voice with theatrical music and sound effects.

THE WAR OF THE WORLDS, The Mercury Theater on the Air, CBS. 30 October I938 http:// www.youtube.com/watch?v=W6YNHqIqc44 (57:34)

Following a news report and studio interview with Professor Richard Pierson, a 'famous astronomer', both he and interviewer Carl Phillips are heard from the scene of a meteorite-like crash in rural New Jersey, alongside an eyewitness interview by a farmer. The descriptions emphasise the incommunicability of this 'fantastic scene.' Listeners are encouraged to listen to the disturbing 
humming sounds of the creature, accompanied by shouts of a crowd and frantic burst of commentary by Phillips who has himself become an eyewitness reporter:

'Ladies and Gentlemen, this is the most terrifying thing I have ever witnessed. (...) Good heavens, something's wriggling out of the shadow like a grey snake. Now it's another one, and another one, and another one! (...) I'll pull this microphone with me as I talk. I'll have to stop the description until I can take a new position. Hold on, will you please, I'll be right back in a minute...' [I5:I5-16:35]

The reporter's anxious commentary is cut off and the suspense is heightened by an interlude of piano music that defers the action temporarily.

The interviewer Phillips returns briefly to describe the attempts of state police to contain the situation after which his nervous reportage describes the action getting closer and closer, as the alien creatures shoot flames, followed by the sounds of hysterical screams, explosions and Philips' microphone falling, following by five tense seconds of silence. In what follows, there are further studio bulletins, army reports and the sounds of battle, with an army battalion whose members lose ground, are heard coughing from smoke attacks and losing their aircraft. The listener at home appears to be a witness to the military's collapse. As the first part of the broadcast draws to a close, a series of radio operators call out to each other with updates, only to be cut off mid-sentence. The final operator calls: 'How's reception? ... How's reception? K, please .... Where are you, $8 \mathrm{X}_{3} \mathrm{R}$ ? ... What's the matter? ... Where are you?' [35:40-36:00]. After a pause of over ten seconds of silence, an announcer is faded in, ostensibly reporting from New York studios, against the intermittent sounds of traffic, boat whistles, droning and tolling bells, with oscillating volume levels. His description of the chaos in the city below, as millions evacuate and the smoke approaches, is also eventually cut off. The listener hears the reporter cough and fall, followed by another exasperating pause of twenty-five seconds of silence. A last desperate call from the operator is heard, before another silence concludes the first half of the broadcast: ' $2 \mathrm{X}_{2} \mathrm{~L}$ calling CQ $\ldots 2 \mathrm{X}_{2} \mathrm{~L}$ calling CQ $\ldots 2 \mathrm{X}_{2} \mathrm{~L}$ calling CQ New York. Isn't there anyone on the air? Isn't there anyone on the air? Isn't there anyone . . 2X2 2 L....' [39:40-40:20].

What these examples illustrate is how this dramatized radio adaptation successfully reproduced the codes of an emergency news broadcast - deploying an acousmatic performance to approximate mass chaos and mental distress for its listening audience. Welles himself remarked on this approximation in his concluding statement: 'We annihilated the world before your very ears, and utterly destroyed the c.B.s.' [58:00-58:Io]. As Jeffrey Sconce has pointed out, this madness or panic broadcast narrates the collapse of three institutions: the American military, the radio network system and the social body..$^{8}$ Sconce reads the popular afterlife of this 'media catastrophe' as being a revealing fantasy narrative about the saturation of radio programming in everyday social life. 39 In an era marked by authoritarian politics and aesthetic conventions, such as the acousmatic 'voice of God' narration in documentary films, the radio programme suggests the considerable impact generated when the usual authority of male voices was undermined. Aesthetically, however, the vocal style remains quite typical of actors dramatizing the conventions of reportage, with its sound effects and musical interludes striking, but consistent with acted studio drama. 
The above example highlights how sonic representations of individual mental distress can hinge on the performance of social and infrastructural collapse. In the recent study Theater of the Mind, Neil Verma suggests that THE WAR OF THE wORLDS formed a contrast to the 'intimate' style of much radio of the I930s, which was a key formula for aligning or 'audiopositioning' listeners with protagonists. Post-war radio plays, as Verma shows, increasingly drew from new models of the psyche drawn from psychoanalysis, psychiatry and psychotherapy..$^{\circ}$ Babble and the staging of inner voices, therefore, entered more mainstream productions, particularly in radio plays dealing with Cold War intrigue. Thrillers and noir programming in American radio, too, have been described as drawing on paranoid concepts of radio as stealing words and thoughts. As Joe Milutis has also noted, radio created a sense of loading 'more voices into the head than the body can withstand', as a corresponding aesthetic development to the claustrophobic interiors and disturbed psychological states of noir film. ${ }^{4 \mathrm{I}}$

\section{Europe}

In contrast to syndicated broadcast for mass network audiences in the United States, we will now introduce a number of radio works drawn from an avant-garde tradition in post-ww II Europe. In these works, the disembodied voice is posited as central to sonic performance of (male) anxiety and madness, albeit with less conventional vocal performances and using new technological possibilities for sound experimentation. Indeed, one of the striking aspects noted about avant-garde radio from the I9IOs onwards is an emphasis on sound and technology, in particular in relation to the body. ${ }^{42}$ Allen $\mathrm{S}$. Weiss has coined the term 'radiophonics' to address a lineage of fragmented radio work extending from the Futurists, Bertolt Brecht, Antonin Artaud and Samuel Beckett, to the more recent works of Gregory Whitehead. ${ }^{43}$ Within this tradition, the medium of radio inspired notions of 'body madness' or 'wireless imagination' (Marinetti) or the 'body without organs' (Artaud). In such images we are reminded of the potential recognised in avant-garde or art radio for investigating themes of disembodiment, interiority, multiple voices and split subjectivities. Nonetheless, as Weiss points out:

"Though the radiophonic voice is "disembodied", the body is never totally absent from radio, while it is often radically disfigured, transformed, mutated. The body is neither purely natural nor purely textual, but rather the primal symbolic system that articulates nature and culture'.44

Weiss' observation provides a reminder about the performance of disturbed or distressed subjectivities by means of acousmatic media like radio do not dispense with the body. Yet at the same time, European avant-garde radio poses a challenge to the style of standard radio practice, which presents a unified and highly conventionalised radio voice. ${ }^{45}$

There are two techniques for speech in avant-garde radio - distortion and glossolalia - that are relevant to the present focus on the performance of mental disturbance. Both these techniques have historically been deployed to challenge presentation style in standard radio practice, which present a unified and highly conventionalised radio voice. The technique of distortion has resulted in experiments to alter speech, for instance with keyboards and vocoders, thus allowing voice to become an abstract sound (or even sound effect), rather than necessarily a carrier of 
linguistic meaning. ${ }^{4}$ The technique of glossolalia - usually referred to as 'speaking in tongues' by voicing babble or nonsense - has featured prominently in the staging of madness, not least due to radio's reputation for presenting the interior of the mind. 47

The two figures discussed most extensively in terms of the use of glossolalia in post-war radio are Antonin Artaud and Samuel Beckett, both already having been involved in the interwar currents of the historical avant-garde and modernism respectively. Artaud's contribution to radio art can be credited to his commissioned piece POUR EN FINIR AVEC LE JUGEMENT DE DIEU [To Have Done with the Judgement of God], which was banned from broadcast by the French radio director in February 1948.

Antonin Artaud, pour en finiR AVEC le JUGement De Dieu [To Have Done with the Judgement of God], recorded 22-29 November 1947 http://www.ubu.com/sound/artaud. html

Artaud's recorded performance was characterised by tirades against America and the Catholic Church, including tortured screams, illogical speech and discordant music. Artaud himself suffered from symptoms of mental illness and was committed to asylums for most of the period I937 to I946, where he received electroshock treatment. Following his work with the Surrealists in the I920s, Artaud had been preoccupied with the notion of a 'Theatre of Cruelty', which would rupture the conventions of the bourgeois theatre:

'This was antinaturalistic, antirealist, and antipsychological theater, where conventional spoken language was often replaced by screams, cries, groans, and other bodily sounds. For both writers and actors, the Theatre of Cruelty was proposed as a form of exorcism, a vehicle for channeling otherwise uncontrollable passions'..$^{8}$

Artaud's voice-oriented theatre concept formed the background to the radio piece, which has been described as inaccessible and disturbing, particularly due to Artaud's own pained vocal performance on the recording. 49

Similar to the mental distress expressed through POUR EN FINIR AVEC LE JUGEMENT DE DIEU, Beckett's absurdist plays and radio work were characterised by tortured characters, as communicated through glossolalia vocal techniques, and for dispensing with the usual conventions of theatrical dialogue, narrative and drama..$^{\circ}$ However, Beckett's portrayal of disembodied voices and split subjectivities drew increasingly on new sound technologies, like audiotape from the I950S. KRAPP'S LAST TAPE (I958), in particular, has been identified as a key text in Beckett's medial investigation of what Schafer dubbed 'schizophonia.' The protagonist Krapp is shown on his sixty-ninth birthday, listening to tapes of himself at the ages of twenty-nine and thirty-nine.

Samuel Beckett, KRAPP'S LAST TAPE (I958). Performed by Harold Pinter in 2006, directed by Ian Rickson http://www.youtube.com/watch?v=YGrfzhOaMkk (8:34)

Katherine N. Hayles has stressed the role of vocal presence and selfhood in KRAPP'S LAST TAPE, focusing on the role of technology in displacing the voice from the body: 
'The immobility of Krapp as he listens establishes a powerful tension between the aural and the visible, between presence as technologically mediated voice and presence as embodiment. (...) The dynamic authorizes two presences onstage: one a voice situated in a human body, the other a voice situated in a machine'..$^{51}$

This multiplied, 'schizoid' voice is enabled through the interactions between Krapp and his voice tapes, whereby the figure onstage is rendered increasingly silent and motionless and ends with the implication of his imminent death. According to this reading, Beckett's play thus not only reveals the on-going investment in the vocal presence as a sign of selfhood and authenticity, but also displaces the subject's conflicted, interior monologue or voices in one's head to the exterior of the recording apparatus.

The examples discussed above indicate how sonic performances of mental distress - in the form of paranoid and schizoid voices, separated from bodies - extended beyond the avant-garde to mainstream radio in post-war North America and Europe. The sense of the voice as displaced or replicated might be said to be primarily conditioned by (tape) recording media. Yet we can also observe the general development towards home stereos and mobile media in the late I950s and I96os with portable radios and tape players allowing for a dispersed site of acousmatic sound across social life. In the case of stereo sound, the sounds split across through two speakers were established as a desirable consumer good, with the control over stereo and high-fidelity sound recouped into the norm and designated as a male domain within bourgeois domesticity. ${ }^{52}$

The uses of disembodied and split voices thematized here were primarily staged within radio, drawing on its status as an acousmatic medium. While the case examples of Welles, Artaud and Beckett made use of sound effects and distortion, it could be argued that these productions preserved the voice as the locus of mental distress. Michel Chion has critiqued such 'vococentrism' in media culture, whereby the spoken voice remains privileged above other elements within the sound narrative. ${ }^{3}$ In the case of radio, the use of distortion techniques, particularly in the German Neue Hörspiel from the I96os onwards, challenged the usual dominance of the voice in radio and blurred the boundaries between voice, music and sound effects. ${ }^{54}$ While writing in the I980s, Chion observed that a significant technological shift had occurred in cinema during the previous decade with the rise of Dolby stereo and sound design. Prior to Dolby stereo, cinema sound usually emanated from a single location, from the centre behind the screen. Sound editors worked with a limited number of tracks and relatively poor quality of sound reproduction with optical soundtracks. In the wake of these developments, Chion characterised the emergence of a so-called sensory cinema, which challenged earlier hierarchies of sound within narrative and the use of generic sound effects. Recent Hollywood productions, with the aid of Dolby, could experiment more with the volume and definition of sound effects. In Chion's words, noises were 'reintroducing an acute feeling of the materiality of things and beings. ${ }^{55}$ It is against this background of heightened sonic effects in film production and cinema reception that we will reflect on how mental disturbance has been sonically mediated in post-war cinema. 


\section{Sonic Approximation in Cinema}

In the existing studies of madness in cinema, most historical accounts mention the visual depiction of a mad protagonist in the German expressionist film THE CABINET OF DR. CALIGARI (Robert Wiene, I9I9). In this silent film, also considered the first modern horror film, the subjective perspective of mental disturbance is primarily approximated through uneven camera angles..$^{56}$ In Anton Kaes' recent analysis of the film, he stresses the starting premise of a man (Francis) attempting to tell his story, like a 'talking cure' in a situation constructed similarly to a psychoanalysis session. The ending of the film provides the revelation that this film narrative has been constructed by a disturbed, or at least unreliable narrator. In Kaes' analysis, the film's aesthetics not only perform the symptoms of Francis' traumatic recall, but the behaviour of Caligari alludes to models of both traditional psychiatry and psychoanalysis existent during World War I. ${ }^{57}$ With the advent of synchronised sound film, a landmark film in rendering the mental disturbance of a child murderer through offscreen sound was Fritz Lang's pioneering film m (I930). In addition to interior perspectives, a key device (and plot resolution) was the use of acousmatic voice, most significantly in the form of the murderer's recognisable whistle.

While there are numerous potential sites for examining the visual representation of madness in post-war film culture, the following will take up a number of cases for the sonic approximation of madness in cinema. A key figure, who worked in scoring practice across both American radio and film (and, later, in television) is the composer Bernard Herrmann (I9II1975). During the I930s, Herrmann worked as a conductor for CBS radio, and arranged scores for radio drama, including the Columbia Workshop and The Mercury Theater on the Air, including Welles' THE WAR OF THE WORLDS' broadcast discussed earlier. Herrmann broke with the usual principle of melodic scoring, instead developing sounds to signal intense disturbances, such as madness and death. Motivic cells and sound effects, rather than developed musical themes, were key to establishing psychological drama and interiority..$^{8}$ This tendency towards layered sound effects and overlapping dialogue can also be identified in Herrmann's score for Orson Welles' first feature film CITIZEN KANE (I94I), which has been described by Rick Altman as achieving a convergence of cinema and radio aesthetics. ${ }^{59}$

The use of sound to establish a sense of psychic collapse - particularly in the tension between voice and body - has been identified as a key characteristic of the films by Alfred Hitchcock (I899-1980) from the late I940s to the early ig6os. In Hitchcock's I945 film SPELlbound, not only the narrative revolves around the relationship between a female psychiatrist and an amnesia patient, but the dramatic score by Miklós Rózsa also made use of eerie electronic sounds of the Theremin to resemble schizophrenia. ${ }^{60}$ In his account of acousmatic sound, Chion has drawn on Hitchcock to elaborate on his understanding of how mediated sound can both establish and disturb voice-body relationships in the cinema. Hitchcock's PsYCHO (I960), with its famous string-based score by Herrmann, has been described as approximating insanity and eruptive forces through its 'music of the irrational. ${ }^{6 r}$ Not only does the expressive score give a sense of the auditory hallucinations of the Norman Bates character, but Chion signals the offscreen voice of his dead mother as an acousmêtre, later revealed to have been voiced by the crazed Bates himself. In the ending, the revelation of the mother's mummified corpse rules out any possibility of witnessing a re-embodiment of the voice. The film, in other words, suggests that it is 
'impossible to reunite the voice with a body that would orient it in space'. ${ }^{62}$ Hitchcock thereby destabilises the illusion created by the cinematic construction of sound-image (and inside-outside), but also thematizes a Freudian notion of the irrational impulses that could puncture the daily order in post-war society.

The notion of acousmatic sound as disturbing and configuring the relationship between voice and body, but also psychic and social space, is also central to Hitchcock's THE BIRDs (I963). Although this film was made fairly soon after PsYCHO, it marked the rise of soundtrack design with new possibilities with sound effects in post-production. Elisabeth Weis, among others, has signalled a shift from the interiority and point-of-view orientation of I95Os films to more visceral and arresting soundtracks. ${ }^{63}$ Herrmann's score for the film deployed low strings to signal psychological disturbance and unease, although electronic instrumentation and post-production process allowed for the innovative spatial arrangements of silence, sparse sound effects and evocative music. ${ }^{64}$ These innovations, as Angelo Restivo has argued, meant that the acousmatic voice could be extended and spatially displaced across the soundscape to the birds. In Restivo's reading, this emphasis on space can be read symptomatically in terms of the rise of television and its role in the larger reconstruction of space and rise of consumer capitalism in the I950s and Ig $^{6} \mathrm{os}^{6}{ }^{65}$ The role of the soundtrack is that it foregrounds 'a new form of subjectivity is produced, one in which experience has become so privatised that public life is continually haunted by that "silent hum" of private enjoyment'. ${ }^{66}$ Where earlier radio and film scoring evoked mental disturbance in relation to interiority, creating a sense of being in someone's head, we can observe a heightened sense of sound space as crucial to establishing disturbances in physical and social space.

Even after the end of his collaboration with Hitchcock in 1966, Bernard Herrmann's scoring techniques were broadly recognised as being effective tools for conveying psychological disturbance. An example of Herrmann's ongoing relevance for 'New Hollywood' directors in the I970s is suggested by his acclaimed score for Martin Scorcese's TAXI DRIVER (I976), released after Herrmann's death in late I975. Herrmann's music has been read as capturing both the protagonist's descent into psychosis and the stifling context of I970s New York. The score's movements each mark a progressively darker mood, with harp arpeggios - used earlier in PsYCHO to signal mental disturbance - are deployed for the film's dramatic ending. ${ }^{67}$ In the example of Herrmann's scoring practice, developed across radio and film from the I930s to I970s, we can observe a challenge to classical film scoring, with psychological horror and mental disturbance achieved through evocative instrumentation, and the destabilisation of classical cinematic vococentrism with the occasional blurring of music, voice and sound effect.

Shortly after the above developments, we can observe a return to a principle of interiority in sound design, although achieved through advancements in the technological rendering of space. In I977, not only the Walkman was invented (Sony TPS-L2), which facilitated individual listening experience via a portable device with headphones, but also the introduction of Dolby sound, which with STAR WARS (1977), signalled new standards in sound recording, design and exhibition. Dolby sound not only allowed for a higher definition sound and multichannel editing, sound designers could place spectators both within a louder, immersive soundscape and a subjective point-of-view. ${ }^{68}$ According to Russell Lack, Dolby loudspeaker placement in the cinema meant that sound "placed at "left" hand and "right" hand to the audience seem to suggest 
oppositional forces, whilst sounds heard as "close up" tend to encourage a kind of participation and those "further away" tend to leave us as observers' ${ }^{69}$ This splitting also suggests additional potential to present schizoid voices through left-right stereo sound placement.

We can trace the above trends in the portrayal of madness in Francis Ford Coppola's APOCALYPSE NOW (I979), another Dolby sound film that has been attributed with pioneering a 'new sound space' and signalling the rise of the sound designer within Hollywood production..$^{\circ}$ At the Cannes premiere of the film APOCALYPSE NOW in I979, the sound designer Walter Murch installed additional speakers in order to create the effect of surround sound. While Coppola's film thematizes and visualises trauma and neurosis during the Vietnam War, the creation of a loud, immersive soundscape heightened the potential for making these disturbances audible and palpable for the cinema audience. Murch further contributed to the portrayal of war-traumatised subjects Captain Willard and Colonel Kurtz, with their disturbed psyches rendered on the level of the soundtrack. APOCALYPSE NOw further changes the usual hierarchies of image over sound, and vococentrism, with its blurring of music and sound affect. From the beginning of the film onwards, the repeated use of The Doors' song 'The End' allows for an innovative link between rock music and warfare and neurosis. In the opening scene of the film, this song mixed with sound effects from helicopters and a ventilator are heard simultaneously, with the overlapping of time and place alluding to Willard's near breakdown. The lyrics - referring to 'the end' - might be said to be performing an interior monologue of the protagonist, and, when combined with the eerie buzzing sounds, are suggested as traumatic cues for the feverish, bed-ridden Willard. ${ }^{1}$

As has been indicated here, the I970s produced a new situation for sound design, with multitrack editing and surround sound, in which mental disturbance increasingly took the forms of electronic sound effect and music. The emergence of a so-called sensory cinema challenged an earlier vococentrism within narrative and more generic use of sound effects. With the rise of digital sound in the I990s, we can observe similar techniques of distortion and immersive soundscapes in the realisation of the disturbed interior world of protagonists. This is particularly striking in, for instance, the dull, throbbing headaches in PI (1998), which are manifested as a claustrophobic, pulsating sound throughout the film, or the paranoia of the main protagonist in TAKE SHELTER (2OII), who has auditory premonitions in the form of the sounds of tidal wave. ${ }^{72}$ These examples of intense subjective sound are aesthetic strategies enabled by the rise of digital sound recording, which as Sean Cubitt already noted in I998, 'alters the metaphorical capacities of sound'. ${ }^{73}$ Despite the new possibilities for manipulating sound with mixing and editing, Cubitt argued that in digital cinema, sound lends itself more easily to spectacle and spatial effect. Mark Kerins, writing on Dolby Digital Sound in 2006, similarly noted that the new immersive aesthetic with surround sound had also affected narrative and visual strategies in production, as the soundtrack is used more for plot information that was traditionally revealed in the image. Against this background, sonic strategies for depicting mental disturbance might reflect a change in which cinematic sound depictions of mental disturbance are necessarily understood as instances whereby the film image is perceived as 'an event of sound and the advent of sound as an event of image'. ${ }^{74}$ Moreover, the study of digital sound, as scholars like Vivian Sobchack and James Tobias have asserted, thus requires not only attention to cross-medial aesthetics, but also multisensoriality in the context of perception.75 


\section{Summary and Synthesis of Trends}

As we have shown, there have been repeated efforts to stage the effects and experience of madness in radio and film history. This trend has been well-documented in the existing scholarship, which has usually focused on the visual representation of madness in modern photography and silent film. Sander Gilman's work, as we pointed out, emphasises the visual in stereotypes of madness due to its immediacy: 'The tradition of visually representing madness in the form of various icons, whether physiognomy or body type, gesture or dress, points towards the need for society to identify the mad absolutely'. ${ }^{6}$ Taking Gilman's influential account as a departure point, we have argued for the necessity to consider how symptoms of madness and anxiety were also staged and approximated in various audio(visual) media. While some of the 'media moments' examined here are usually studied in isolation, this article has offered a first synthesis of trends in broadcast and cinema culture, with a concentration on developments between the I930s and I970s. ${ }^{77}$ Whereas much of the existing scholarship was articulated in terms of psychoanalytic film theory, we sought to deepen these accounts with more attention to the particular technological and social developments in which any particular media text is produced.

Acousmatic sound provides an important blueprint for the examination of mental disturbance in twentieth-century modernity, whether figuring as an inherent medial characteristic (of the radio and telephone) or narrative device (by means of music, voice, ambient sound and effects). In each of the case studies examined in this paper, the relationship of mediated sound (and the voice in particular) to the body are crucial for thinking through modernity's shattering and reconstruction of subjectivity. Accordingly, we have examined advancements in radio techniques and the rise of sound film from the I930s in relation to key instances of the staging (or even inciting) mental disturbances in the radio work of Artaud, Beckett and Welles. ${ }^{8}$ In the post-war period, we traced the process in which music and sound effects have come to take on a life on their own, with artistic strategies gradually shifting away from an earlier vococentrism. In the I960s and I970s, parallel to the rise of the anti-psychiatry movement and the process of deinstitutionalisation of the mentally ill, we traced the aesthetic shift from split voices to experimentation of dispersed voices in space, as can be found in the collaborations between Herrmann and Hitchcock. We have indicated how this broader shift was accelerated by the rise of Dolby sound in the late I970s, which provided new technological means for manipulating sound in production and reception. These post-war innovations in stereo and surround sound have provided a means for new aesthetic encounters with mental disturbance and traumatic memory by means of sound.

The present analysis suggests a certain continuation of dispersed and surround sound in the approximation and representation of mental illness, which spans from the I970s Dolby sound design into the era of digital cinema and broadcasting. Indeed, we might observe an ongoing aesthetic strategy of immersive cinema soundscapes that approximate mental disturbance and auditory hallucinations for its audiences. Radio broadcasting, too, not only often thematizes the experience and stigma of mental illness, but being involved in radio production has been affirmed as facilitating patient therapy and outreach.79 Despite such continuities, John Peters has argued that the digital media landscape has produced a profound change in public discourse and communication practice: 
'What was once mad or uncanny is now routine: hearing disembodied voices and speaking to nobody in particular. [...] Schizophrenia's vocal-aural delusions fit with the radio, television, and telephone, media that were saturated with nonverbal codes and simulated sociability. Digital media, in contrast, favor data-processing and logistical convenience over the staging of face-to-face interaction. The "it" disease for new media, with their low-affect machine interfaces, appears to be autism'..$^{\circ}$

In other words, media practices like mobile phone speech, texting and tweeting produce similar behaviours to those previously diagnosed as a confusion of broadcast address, such as thought transference and delusions of transfer. Where broadcast address once figured a test for sanity, it is no longer the audiovisual that figures centrally to media communication, but rather digital media interfaces.

\section{Notes}

I J.D. Peters, 'Broadcasting and Schizophrenia', in: Media, Culture \& Society, 32, I, 20IO, p. I23-I40, here p. I32.

2 S.L. Gilman, Seeing the Insane, John Wiley, New York et. al. I982.

3 Gilman, Seeing the Insane, p. xii.

4 For the rise of visual culture studies, see for instance, R. Krauss \& H. Foster, 'Introduction' in: Visual Culture.

Special Issue of October 77, I996, p. 3-4; M. Bal, 'Visual Essentialism and the Object of Visual Culture', in: Journal of Visual Culture, 2, I, 2003 , p. 5-32.

5 For an elaborate account on the relationship between psychiatry and photography during the late nineteenth century, see G. Didi-Huberman, Invention of Hysteria: Charcot and the Photography Iconography of the Salpêtrière, trans. A. Hartz, MIT Press, Cambridge ma 2003 [1982].

6 He quotes at length Sigmund Freud's student Theodor Reik, who also posited the psychoanalytic situation in aural terms, using the metaphor of the 'third ear'. See: T. Reik, Listening with the Third Ear: The Inner Experience of a Psychoanalyst, Farrar, New York I948; Gilman, Seeing the Insane, p. xiii, 223-224.

7 See, for instance, M. Fleming \& R. Manvell, Images of Madness: The Portrayal of Insanity in the Feature Film, Fairleigh Dickinson University Press, Rutherford NJ I985; K. Gabbard \& G.O. Gabbard, Psychiatry and the Cinema, University of Chicago Press, Chicago I987, and L.A. Sass, Madness and Modernism - Insanity in the Light of Modern Art, Literature and Thought, BasicBooks, New York 1992. In this article, televisual depictions of madness will only receive short shrift. For more extensive studies of television representations, see, for instance, G. Philo, The Media and Mental Distress, Addison Wesley Longman, London I996. Otto Wahl points out that '[a]lmost all drama series on television have found occasion to portray mental illness'. See O.F. Wahl, Media Madness: Public Images of Mental Illness, Rutgers University Press, New Brunswick NJ I995, p. 9.

8 See F.A. Kittler, Gramophone, Film, Typewriter, trans. G. Winthrop-Young \& M. Wutz, Stanford University Press, Stanford I999; W. Hagen, 'Der Radioruf: Zu Diskurs und Geschichte des Hörfunks', in: M. Stingelin \& W. Scherer (eds), Hardwar/Softwar: Krieg und Medien 1914 bis 1945, Fink, Munich I99I, p. 247-257.

9 Indeed, the technologically-informed 'modern auditory self' - who had to overcome assaults on the senses and nerves - raises the decisive issue of the conceptual interplay between modern listening, media and mental disturbance around I900. See, for instance, Benjamin's notion of cinema as a 'training ground' [Übungsinstrument] that can help the subject to deal with modern experiences of shock and overstimulation. See: W. Benjamin, The Work of Art in the Age of Its Technological Reproducibility, and Other Writings on Media, ed. M. W. Jennings et. al., Belknap, Cambridge MA 2008; S. Connor, 'The Modern Auditory I', in: R. Porter (ed.), Re-writing the Self: Histories from the Renaissance to the Present, Routledge, London I997, p. 203-223.

Io J. Sterne, The Sound Studies Reader, Taylor \& Francis, London 20I2; T. Pinch \& K. Bijsterveld (eds.), The Oxford Handbook of Sound Studies, Oxford University Press, Oxford 2012; Michele Hilmes, 'Is There a Field Called Sound Culture Studies? And Does It Matter?', in: American Quarterly, 57, I, 2005, pp. 249-259. Holger Schulze, Sound Studies: Traditionen-Methoden-Desiderate. Eine Einführung, transcript Bielefeld, 2008. 
II For Chion's writing on acousmatic sound, see M. Chion, Audio-Vision: Sound on Screen. Ed. and trans. Claudia Gorbman. Columbia up, New York 1994; Michel Chion, The Voice in Cinema. Trans. Claudia Gorbman, Columbia up, New York I999.

I2 For an account of the symptoms identified in clinical diagnoses, see R. Noll, The Encyclopedia of Schizophrenic and Other Psychotic Disorders, Infobase Publishing, New York 2009.

I3 C. Anderson \& M. Curtin, 'Writing Cultural History: The Challenge of Radio and Television', in: N. Brugger and S. Kolstrup (eds), Media History: Theories, Methods and Analysis, Aarhus University Press, Aarhus 200I, p. I7.

I4 See, for instance, Jeffrey Sconce's examination of metaphors used for electronic media from the invention of the telegraph to the introduction of television and computers. J. Sconce, Haunted Media: Electronic Presence from Telegraphy to Television, Duke University Press, Durham NC 2000. For accounts of pathologies of railway trains and the cinema, see W. Schivelbusch, The Railway Journey: The Industralization of Time and Space in the 19th Century, University of California Press, Berkeley CA I986; L. Kirby, Parallel Tracks: The Railroad and Silent Cinema, Duke University Press, Durham NC 1997 .

I5 See, for instance, T. Campbell, Wireless Writing in the Age of Marconi, University of Minnesota Press, Minnesota 2006; R. Gallo, Mexican Modernity: The Avant-Garde and the Technological Revolution, The MIT Press, Cambridge MA 2010, p. I30.

I6 See, for instance, Adolf Uzarski's 1929 account of his brother acting like a radio crazy (Radiot) in I924. A. Uzarski, 'Wie ich Radiot wurde', in: Jahrbuch des Westdeutschen Rundfunks 1929, Rufu-Verlag, Cologne I929, p. 3I33. On Uzarski's development of a comic style for discussing radio, see F. Steinfurt, “Wie ich Radiot wurde”: Der Erfinder der Rundfunkgroteske Adolf Uzarski', in: A. Johanning \& D. Lieser (eds), Stadt-Land-Fluss. Urbanität und Regionalität in der Moderne: Festschrift für Gertrude Cepl-Kaufmann zum sechzigsten Geburtstag, Ahasvera, Neuss 2002, p. I29-I49. For a similar discussion of sound telegraphy operators, see J. Sterne, The Audible Past: Cultural Origins of Sound Production, Duke University Press, Durham 2003.

I7 Susan Douglas has conceptualised this early wireless listening or 'DXing' in I920s America as a mode of 'exploratory listening'. See: S.J. Douglas, Listening In: Radio and the American Imagination, University of Minnesota Press, Minneapolis and London 2004 [I999], p. 55-82.

I8 See Andreas Killen's analysis of hysteria and neurasthenia in the case of female typists and telephone operators in the decades around I900: A. Killen, Berlin Electropolis: Shock, Nerves and German Modernity, University of California Press, Berkeley and Los Angeles 2006, p. I62-2II.

I9 See, for instance, E. Rosenhaft, 'Lesewut, Kinosucht, Radiotismus: Zur (geschlechter-)politischen Relevanz neuer Massenmedien in den I920er Jahren', in: A. Lüdtke, I. Marßolek \& A. von Saldern (eds), Amerikanisierung: Traum und Alptraum im Deutschland des 20. Jahrhunderts, Steiner, Stuttgart I996, p. II9-I43.

20 For the military origins and uses of (sound) technologies in the nineteenth and early twentieth century, see: Kittler, Gramophone, Film, Typewriter; Hagen, 'Der Radioruf: Zu Diskurs und Geschichte des Hörfunks'.

2I Douglas, Listening In, p. 200. See also: K. Lacey, 'Radio in the Great Depression: Promotional Culture, Public Service, and Propaganda', in: M. Hilmes \& J. Loviglio (eds), Radio Reader: Essays in the Cultural History of Radio, Routledge, New York 2002, p. 2I-40; F. Dyson, 'The Genealogy of the Radio Voice', in: D. Augaitus \& D. Lander (eds), Radio Rethink: Art, Sound and Transmission, W.P. Gallery, Banff ı994, p. I67-I86.

22 Douglas elaborates on sports broadcasting as an arena in which male emotions could be expressed: 'from lowkey dispassion to barely repressed hysteria. (...) Ironically, in listening to something rugged like sports, an act which in itself confirmed one's manhood, one could let loose and verbally and physically express joy, elation, worry, hope, despair, and a deep attachment to others without becoming feminized'. See Douglas, Listening In, p. 2I7.

23 See for instance, Avital Ronell's extensive discussion of the telephone in relation to psychoanalysis and schizophrenia in A. Ronell, The Telephone Book: Technology - Schizophrenia - Electric Speech, University of Nebraska Press, Lincoln NE I989.

24 Kittler, Gramophone, Film, Typewriter.

25 Chion draws on the notion of 'acousmatique' sound art as developed by French musique concrète composer Pierre Schaeffer. See: Chion, Audio-Vision; Chion, The Voice in Cinema.

26 Chion, Audio-Vision, p. 2I-22. A summary of film and psychoanalysis in connection to visual and narrative analysis can be found in H. Kappelhoff, 'Kino und Psychoanalyse', in: J. Felix (ed.), Moderne Film Theorie, Bender Mainz 2002, pp. I30-I59; Markus Fellner, Psycho Movie: Zur Konstruktion psychischer Störung im Spielfilm, transcript Bielefeld 2006 .

27 J.D. Peters, 'Broadcasting and Schizophrenia', p. I23-I40. See also: D. Schrage, Psychotechnik und Radiophonie: Subjectkonstruktion in artifiziellen Wirklichkeiten 1918-1932, Wilhelm Fink Verlag, Bonn 200I; W. Hagen, “Was mit Marconi begann...": Radio und Psychoanalyse', Die Neue Rundschau, 4, 200I, p. 2I-36. 
28 As Peters points out, this conviction had a major influence on a wide range intellectuals in the early to mid-twentieth century, mentioning names such as Gregory Bateson, Bruno Bettelheim, Margaret Mead, Michel Foucault, Frantz Fanon, Erving Goffmann, Jürgen Habermas, Jacques Lacan etc. See Peters, 'Broadcasting and Schizophrenia', p. 137 .

29 See, for instance, Peters' discussion of the work of Friedrich Kittler and Wolfgang Hagen in this context. Peters, 'Broadcasting and Schizophrenia', p. I32. Hagen in particular, has examined the parallels between spiritualism and sound media around I900, with particular attention to the symptoms resembling telegraphy - as 'thought transference' - in figures like Daniel Paul Schreber in this period. See W. Hagen, Radio Schreber: Der 'moderne Spiritismus' und der Sprache der Medien, Verlag und Datenbank für Geisteswissenschaften, Weimar 200I. Also on: www.whagen. de/publications/RadioSchreber/radioschreber.htm

30 Peters, 'Broadcasting and Schizophrenia', p. I27.

3I Peters, 'Broadcasting and Schizophrenia', p. I3I.

32 See Douglas, Listening In.

33 For listener statistics, see Douglas, Listening In, p. I65.

34 Listener cited in Howard Koch, Panic Broadcast: The Whole Story of Orson Welles' Legendary Radio Show “Invasion from Mars", Avon, New York I970, p. 97, qtd. in Sconce, Haunted Media, p. II7.

35 The disorientation generated by news stories is consistent with the rise of the American nationally-syndicated series THE MARCH OF TIME, which began in I928 as a dramatised actor performance of Time Magazine's most exciting articles. The programme was later expanded, from I93I, for a larger listening audience, with actors, a live orchestra, and performed sound effects. Welles worked briefly on the programme in I935, which was among his first engagements in radio. See, for instance, L. Lichty \& T.W. Bohn, 'Radio's "March of Time”', in: Journalism Quarterly, I974, p. 458-462; W. Faulstich, Radiotheorie: Eine Studie zum Hörspiel 'The War of the Worlds' (1938) von Orson Welles, Narr, Tübingen I98I, p. 3I-32; N. Verma, Theater of the Mind: Imagination, Aesthetics, and American Radio Drama, University of Chicago Press, Chicago 20I2, p. 66.

36 For the details of this broadcast, see L. Lichty, 'Hindenburg crash coverage', in: D.G. Godfrey \& F.A. Leigh (eds), Historical Dictionary of American Radio, Greenwood Press, Westport I998, p. I97-I98.

37 Although the premise of an alien landing was less than plausible, the broadcast's reportage style was crucial to its effectiveness, as director Paul Stewart also pointed out: 'We all agreed that its only chance of coming off lay in emphasizing its newscast style - its simultaneous, eyewitness quality'. Peter Stewart, quoted in M. Hilmes, Radio Voices: American Broadcasting, 1922-1952, University of Minneapolis Press, Minneapolis I997, p. 223.

38 Sconce, Haunted Media, p. II4

39 Sconce, Haunted Media, p. II7.

40 Verma, Theater of the Mind, p. 2II-2I2.

4I J. Milutis, 'Radiophonic Ontologies and the Avantgarde', in: TDR (The Drama Review, mIT Press) 40, 3, Autumn I996, p. 65 .

42 There are several important volumes documenting the fragmentary avant-garde radio tradition. See: N. Strauss (ed.), Special issue: Radiotext(e), in: Semiotext(e), 6, I, I993; D. Kahn \& G. Whitehead (eds), Wireless Imagination: Sound, Radio and the Avant-garde, MIT Press, Cambridge \& London I994; D. Augaitus \& D. Lander (eds.), Radio Rethink: Art, Sound and Transmission, W.P. Gallery/Banff Centre Press, Banff I994; B. LaBelle \& E. Granly Jensen (eds), Radio Territories, Errant Bodies Press, Los Angeles 2007. For an instructive essay on avant-garde radio, also in reference to Artaud and Beckett, see Milutis, 'Radiophonic Ontologies and the Avantgarde', p. 63-79.

43 A 'radiophonic' approach has been identified in radio art projects that interrogate the schizophonic condition, radio interiority, and the separation of voices from the body. G. Whitehead, 'Holes in the Head: Theatres of Operation for the Body in Pieces', in: Augaitus Lander (eds), Radio Rethink: Art, Sound and Transmission, p. I55; G. Whitehead, 'Radio Play is No Place: A Conversation between Jérôme Noetinger and Gregory Whitehead', in: TDR , 4O, 3, Autumn I996, p. I0I; A.S. Weiss, Phantasmic Radio, Duke University Press, Durham i995; Milutis, 'Radiophonic Ontologies', p. 65-66.

44 A.S. Weiss, 'Radio Icons, Short Circuits, Deep Schisms', in: TDR, 40, 3, Autumn I996, p. I2.

45 See M. Shingler, 'Some Recurring Features of Avant-Garde European Radio', in: Journal of Radio Studies, 7, I, 2000 , p. I98.

46 For an elaboration on the significance of voice technologies like the Voder and Sonovox in American radio and film during the I940s, see J. Smith, 'Tearing Speech to Pieces: Voice Technologies of the I940s', in: Music, Sound and the Moving Image, 2, 2, 2008, p. 183-206.

47 For the broader history of glossolalia, particularly in relation to religious movements like Pentecostelism, see M.J. Cartlidge (ed.), Speaking in Tongues: Multidisciplinary Perspectives, Paternoster Press, Milton Keynes 2006. Al- 
ready from the I9IOs, the Futurists advocated unconscious and free speech forms for radio, described as 'words freed from conventional syntax and associative meaning, enabling words to float free as sound, as abstractions, allowing listeners to enjoy their rhythmic, melodious, and tonal qualities'. Shingler, 'Some recurring features', p. 204.

48 Shingler, 'Some recurring features', p. 204.

49 See, for instance, K. Branigan, Radio Beckett: Musicality in the Radio Plays of Samuel Beckett, Peter Lang, Bern and Oxford 2008, p. I88. For more on Artaud's sound-based theatre concept and its challenge to verbal language, see D. Hollier, 'The Death of Paper, Part Two: Artaud's Sound System', October, 80, I997, p. 27-37.

50 In 'Rough for Radio II', first written in French in I96I, the later BBC broadcast drew on the voice as an affective tool for communicating psychological anguish through screams, cries and fragmented speech. Branigan, Radio Beckett, p. I8I-I84.

5I K.N. Hayles, 'Voices out of Bodies, Bodies out of Voices: Audiotape and the Production of Subjectivity', in: A. Morris (ed.), Sound States. Innovative Poetics and Acoustical Technologies, The University of North Carolina Press, Chapel Hill \& London I998, p. 82-83. For a more elaborate discussion of schizophonia in Beckett's post-war plays, see also L. Sinoimeri, “Close your eyes and listen to it”: Schizophonia and Ventriloquism in Beckett's plays', in: Miranda, 4, 20II. URL: <http://www.miranda-ejournal.fr/I/miranda/article.xsp?numero=4\&id_article=Article_04-938>. Last accessed I5 May 20 I2.

52 See, for instance, K. Keightley, “Turn It Down!” She Shrieked: Gender, Domestic Space, and High Fidelity, I94859', in: Popular Music, I5, 2, I996, p. I49-I77; H. Weber, Das Versprechen mobiler Freiheit: Zur Kultur- und Technikgeschichte von Kofferradio, Walkman und Handy, transcript Verlag, Bielfeld 2008. See also Rainer Werner Fassbinder's films of the I970s, where acousmatic voices from sound technologies within his film diegesis were foregrounded as a way to convey societal chaos. See S. Siewert. Fassbinder und Deleuze, Tectum, Marburg 2009.

53 See, for example Chion, The Voice in Cinema. For the role of sound in classical narrative and the hierarchies within the classical Hollywood soundtrack, see M.A. Doane, 'Ideology and the Practices of Sound Editing and Mixing', in: T. de Laurentis \& Stephen Heath (eds), The Cinematic Apparatus, Macmillian London I980; A. Williams, 'Is Sound Recording Like a Language', in: Yale French Studies, 60, I980, pp. 51-66.

54 Shingler, 'Some recurring features', p. 206-208.

55 Chion, Audio-Vision, p. I55.

56 See, for instance, Fleming \& Manvell, Images of Madness, p. 3, 56; see also Richard Noll's encyclopedic entry for 'Motion Pictures', which mentions early cinema depictions of madness in the period I904-I906. R. Noll, The Encyclopedia of Schizophrenic and Other Psychotic Disorders, Infobase Publ., New York 2009, p. 282.

57 A. Kaes, Shell Shock Cinema: Weimar Culture and the Wounds of War, Princeton UP, Princeton 2009, p. 49-54.

58 See S. Smith, A Heart at Fire's Center: The Life and Music of Bernard Herrmann, University of California Press, Berkeley/Los Angeles 2002, p. II3, I85. See also the reflections of Herrmann's colleague and partner, Lucille Fletcher, in: L. Fletcher, 'Squeaks, Slams, Echoes and Shots', in: New Yorker, April I3, I940, p. 8I-96, cited in N. Verma, Theater of the Mind, p. 9I, 94.

59 Altman sees in this film a proto-model for television sound, which draws on both radio (sense of interiority) and film sound (in the principle of audiovisual continuity). See R. Altman, 'Deep-focus Sound: Citizen Kane and the Radio Aesthetic', in: Quarterly Journal of Film Q Video, 15, 3, I994, p. I-33. For a more extended discussion of radio and film as models for televisual sound aesthetics, see C. Birdsall and A. Enns, 'Rethinking Theories of Television Sound', Journal of Sonic Studies, 3, 20I2, n.p. URL: <http://journal.sonicstudies.org/volo3.nroI/aoI>. Last accessed I March 2013.

6o Rózsa's other scores for Hollywood film noirs - such as DOUBLE INDEMNITY (I944), THE KILLERS (I946) and THE NAKED CITY (I948) - were also characterized by a similar stress on interiority and mental disturbance. See R. Lack, Twenty Four Frames Under: Buried History of Film Music, Quartet Books, London I997, p. 137-I39. For the use of the Theremin in I950s sci-fi and other genres, see J. Wierzbicki, 'Weird Vibrations: How the Theremin Gave Musical Voice to Hollywood's Extraterrestrial “Others"', in: Journal of Popular Film and Television, 30, 3, 2002, p. I25-I35.

6I The most famous scoring discussed in relation to this film is the shrieking violin glissandi that stand in for Marion's screams when being attacked by the unseen assailant (Norman Bates) while in the shower. R.S. Brown, 'Herrmann, Hitchcock and the Music of the Irrational', in: Cinema Journal, 2I, 2, 1982, p. I4-49. See also R. Lack, Twenty Four Frames Under, p. I34-I35.

62 Chion, The Voice in Cinema, p. I40-I51. Chion argues that Hitchcock makes a distinction between the more usual 'internal voices' heard by Marion while driving her car and the sign of insanity generated by the 'I-voice' of the mother when Norman Bates is in his cell. See Chion, The Voice in Cinema, p. $5 \mathrm{I}$.

63 See E. Weis, The Silent Scream: Alfred Hitchcock's Sound Track, Fairleigh Dickinson University Press, Rutherford NJ I982; E. Weis, 'The Evolution of Hitchcock's Aural Style and Sound in The Birds', in: E. Weis \& J. Belton (eds), Film Sound: Theory and Practice, Columbia University Press, New York 1985, p. 298-3II. 
64 On the innovations of the soundtrack for THE BIRDS, see Steven Smith, A Heart at Fire's Center, p. I85; Brown, 'Herrmann, Hitchcock and the Music of the Irrational'; A. Restivo, 'The Silence of The Birds: Sound Aesthetics and Public Space in later Hitchcock', in R. Allen \& S. Ishii-Gonzáles, Hitchcock: Past and Future, Routledge, Abingdon Oxon 2004, p. 164-I78.

65 Restivo draws on the psychoanalytically-informed work of Zizek and Chion in his reading of the film's soundtrack. 66 Restivo, 'The Silence of The Birds', p. I75.

67 See Lack, Twenty Four Frames Under, p. 327, 352.

68 For more on the introduction of the Walkman and the accompanying rise of headset culture, see M. Bull, Sounding out the City: Personal Stereos and the Management of Everyday Life, Berg, Oxford 2000. For historical perspectives on the earlier uses of headphones, for instance in early radio, see T.D. Taylor, 'Music and the Rise of Radio in I920s America: technological imperialism, socialization, and the transformation of intimacy', Historical Journal of Film, Radio and Television, 22, 4, 2002, p. 424-443.

69 Lack, Twenty Four Frames Under, p. 321; Chion, The Voice in Cinema, p. I66-I69.

70 For a more extensive analysis of the film soundtrack and its production, see: T. Elsaesser \& M. Wedel, 'The Hollow Heart of Hollywood: Apocalypse Now and the New Sound Space', in: M. Moore (ed.), Conrad on Film, Cambridge University Press, Cambridge I997, p. I5I-I75. See also: G. Sergi, The Dolby Era: Film Sound in Contemporary Hollywood, Manchester University Press, Manchester 2004.

7I For similar use of pop songs in films since the I990s in connection with drug use and mental distress, see S. Siewert, Entgrenzungsfilme. Jugend, Musik, Affekt, Gedächtnis: Eine pragmatische Poetik zeitgenössischer europäischer Filme, Schüren, Marburg 2013.

72 More generally since the I990s there has been a renewed interest in mental displacements, with a return to the head and perception as the site of disturbance. In these so-called 'Mind-Game' films, as they are described by Thomas Elsaesser, questions of psychology and psychopathology are raised in new ways. Most characters are also suffering from amnesia, schizophrenia or paranoia and tackle the spectator-film relation. See Thomas Elsaesser, 'The MindGame Film', in: Warren Buckland (ed.), Puzzle Films: Complex Storytelling in Contemporary Cinema. Wiley-Blackwell, Chichester 2009, p. I3-4I.

73 S. Cubitt, Digital Aesthetics, Sage, London I998, p. Iı6.

74 V. Sobchack, 'When the Ear Dreams: Dolby Digital and the Imagination of Sound', in J. Khalip \& R. Mitchell (eds), Releasing the Image: From Literature to New Media, Stanford University Press, Palo Alto 20II, p. I3.

75 James Tobias, 'Cinema, Scored: Toward a Comparative Methodology for Music in Media', in: Film Quarterly, 57, 2, 2003, p. 26-36.

76 S. Gilman, Disease and Representation, Cornell University Press, Ithaca NY I988, p. 48.

77 Nonetheless, the existing article has primarily examined media productions that foreground crises of male voices and subjectivities, which provides a rationale to extend the existing corpus in subsequent research. For more expanded gender readings of women's film in relation to madness and hysteria see A. Lawrence, Echo and Narcissus: Women's Voices in Classical Hollywood Cinema, University of California Press, Berkeley and Los Angeles I991; see also J. Smith, 'Tearing Speech to Pieces'; K. Kalinak, Settling the Score: Music and the Classical Hollywood Film, University of Wisconsin Press, Madison I992; C. Flinn, Strains of Utopia: Gender, Nostalgia, and Hollywood Film Music, Princeton University Press, Princeton I992; C. Flinn, The New German Cinema: Music, History, and the Matter of Style, University of California Press, Berkeley/Los Angeles CA 2004.

78 Another relevant case of madness in radio, although not be discussed here, is that of the modernist author Ezra Pound. Pound, who had been in asylums for over a decade, subsequently delivered broadcasts in fascist Italy during World War Two, and claimed insanity when he was later trialled for his activities. See: D. Tiffany, Radio Corpse: Imagism and the Cryptaesthetic of Ezra Pound, Harvard University Press, Cambridge i995; J. Lewty, "What They Had Heard Said Written”: Joyce, Pound, and the Cross-Correspondence of Radio', in: D.R. Cohen, M. Coyle \& J. Lewty (eds), Broadcasting Modernism, University Press of Florida, Gainesville 2009, p. 199-220.

79 See, for instance, T. Bonini, 'Crazy Radio: The Domestication of Mental Illness over the Airwaves', in: The Radio Journal, I3, 3, 2005, p. I45-53. Examples of radio broadcasts that have sought to provide insights into mental illness include This American Life's EDGE OF SANITY (I997) and Wibke Bergemann's WenN DIE PSYCHE ZERSPLITTERT (20II). On the role of music and radio within asylum treatment and historical discourses of madness, see D. MacKinnon, 'Music, Madness and the Body: Symptom and Cure', in: History of Psychiatry, I7, 9, 2006, p. 9-2I; D. MacKinnon, “'Amusements are Provided”: Asylum Entertainment and Recreation in Australia and New Zealand c. I860-c.I945', in: G. Mooney \& J. Reinarz (eds), Permeable Walls: Historical Perspectives on Hospital and Asplum Visiting, Rodopi, Amsterdam \& New York 2009, p. 267-288.

80 Peters, 'Broadcasting and Schizophrenia', p. 138 